\title{
Solidarity (Solidarność) at Forty: Memories and Influences on Contemporary Poland Does Solidarity Still Matter?
}

\author{
Richard J. Hunter, Jr.* Héctor R. Lozada \\ Stillman School of Business, Seton Hall University, South Orange, New Jersey 07079 United States
}

This paper is dedicated to the memory of Brother Leo V. Ryan, C.S.V., who passed away in 2016.

\section{Abstract}

Part I of the paper is a retrospective on the origins of the Solidarity Movement in Poland and the economic program it introduced after its assumption of power in 1989. Part II outlines various challenges faced by Polish society in light of current political configurations and discusses Solidarity's contemporary relevance on the political and economic calculus of Poland. This retrospective is based on more than thirty-five years of research and analysis on the Polish economic and political scenes.

Keywords: Poland, Polish Economy, Solidarity Movement, JUST REMEMBER: STALIN HIMSELF WAS REPORTED TO HAVE STATED THAT "SOCIALISM WOULD FIT POLAND LIKE A SADDLE WOULD FIT A COW."

DOI: $10.7176 / \mathrm{EJBM} / 11-23-12$

Publication date: August $31^{\text {st }} 2019$

\section{Part I - A Retrospective}

1. The Roots of Solidarity" 1956, 1968, 1970, 1976

We are now approaching the fortieth anniversary of the Solidarity Movement's breakout in Gdansk, Poland in the summer of 1980. A retrospective and evaluation are certainly in order. The lessons of Solidarity are especially instructive for the Poland of today. The roots of Solidarity in Polish society were both wide and deep and were developed from decades of struggles by Polish workers, students, and intellectuals against the communist system.

\subsection{Poznan}

Protests in Poznan broke out in 1956. These protests are also known as the Poznan Uprising or the Poznan June (in Polish, Poznański Czerwiec), and were the first of several recorded mass protests against the government of People's Poland. The demonstrations were carried out by workers who demanded better working conditions and pay raises. They began on June 28, 1956 at the Cegielski Factory and were met with violent repression by the government.

The protests began when a crowd of approximately 100,000 workers and others gathered in the city center near the local Ministry of Public Security building clamoring for "bread and freedom" (Hunter \& Ryan, 1998). The government reacted swiftly and directly. About 400 tanks, 10,000 Polish soldiers, and the Internal Security Corps (in Polish, Korpus Bezpieczeństwa Wewnętrznego - KBW), under a Polish-Soviet general Stanislav Poplavsky, were ordered to suppress the demonstrations. During the process, the protestors were fired on. [The KBW was a special-purpose military formation established by the pro-Soviet Council of Ministers on May 24, 1945.]

The death toll was placed between 57 to over a hundred people, including a 13-year-old boy named Romek Strzałkowski, who became one of the best-known symbols of anti-communist resistance in Poland. Hundreds of the demonstrators sustained injuries. The events of 1956 resulted in the reinstatement of Wladyslaw Gomulka as first secretary of the Polish Communist Party. Gomulka had been ousted as First Secretary in 1948, although he remained as vice premier until January 1949, and as a member of the Central Committee of the Communist Party until 1951. Gomulka was indeed fortunate. "Gomulka was never subjected to a public trial or shipped to a "gulag" in the Soviet Union" (Hunter \& Ryan, 1998, p. 27).

As an aftermath of the Poznan June, there was an anticipation of change and reform. Gomulka stated: "The causes of the Poznan tragedy and of the deep dissatisfaction of the entire working class lie within us, in the Party and in the government" (Goodwyn, 1991, p. 74). The early optimism would be short-lived.

\subsection{Warsaw and the March Events}

Initially, Poland under Gomulka experienced a period of economic growth. New apartments were constructed and prices for basic consumer goods were rolled back by the government. Collectivization of the agricultural sector was essentially abandoned. Gomulka also attempted to establish cordial relations with the Polish Catholic Church. Cardinal Stefan Wyszynski, the Polish Primate, was freed from house arrest (generally, Micewski, 1984). However, seemingly unrelated events would overwhelm attempts at real reform, as the idea of central management and 
planning were in fact strengthened and further institutionalized under Gomulka (Balcerowicz, 1995, pp. 52-55).

A series of crises would eventually drive Gomulka from power. The March 1968 Events (in Polish, Marzec 1968 or wydarzenia, wypadki marcowe) related to a protest by students and intellectuals in Warsaw, who were reacting to the banning by communist authorities of a play Dziady (Forefather's Eve), written by Adam Mickiewicz, under orders by the Soviet Union, when the Soviet ambassador complained to Polish authorities that the play was anti-Soviet. The crisis resulted in the suppression of student strikes by security forces not only in Warsaw but also in major academic centers across the country and the subsequent repression of the nascent Polish dissident movement. In Krakow, for example, the Market Square was surrounded by members of the ORMO (in Polish, Ochotnicza Rezerwa Milicji Obywattelskiej) factory police. Buildings at the Jagiellonian University were attacked by a riot squad brandishing clubs and tear gas.

In Warsaw, the government demagogued the crisis by claiming that the students and intellectuals who came to their assistance were being supported by anti-Polish and pro-Zionist elements in society. In actuality, the government's anti-Jewish campaign had begun in 1967. The policy was carried out in conjunction with the Soviet Union's withdrawal of diplomatic relations with Israel after the Six-Day War. On the micro level, the events in Poland also involved a power struggle within the Polish Communist Party itself between Gomulka and the violently anti-Semitic General Mieczyslaw Moczar. The subsequent purges within Poland's ruling party failed to topple Gomulka's government, but did result in the exodus from Poland of thousands of individuals of Jewish ancestry (reports indicated that the number approached 13,000), including professionals, party officials, and academics. Many relocated either in Israel or in the United States. Sadly, these individuals represented a large portion of the remaining Jewish population of Poland who had survived World War II. In an ironic twist, Gomulka's own wife was Jewish.

The events of 1968 exposed a fissure between Polish workers and Polish intellectuals and students who were on opposite sides of the struggle. Carefully staged public demonstrations of support of the government were carried out by factory workers across Poland (but most especially in Warsaw). The Polish press called upon workers to defend the nation against "Zionist traitors" and the workers responded with violence.

The protests in Poland coincided with the events of the "Prague Spring" (in Czech, Pražské jaro; in Slovak, Pražská jar) in neighboring Czechoslovakia, led by Alexander Dubcek and Ludwik Swoboda, in which intellectuals, students, and workers had banded together seeking economic and political reform. The unrest in Czechoslovakia was only quelled with the invasion of Czechoslovakia by forces of the Warsaw Pact on August 20, 1968 - including troops from Poland. Only Romania and Albania refused to participate in the invasion.

\subsection{The Events of 1970}

In December 1970, the government unexpectedly announced massive increases in the prices of basic foodstuffs in the range of 12 to 36 percent, clumsily during the two-week period preceding Christmas. Strikes and demonstrations broke out among workers of the northern Baltic coastal cities of Gdansk, Gdynia, Elblag and Szczecin. Gomulka's chief adviser, Zenon Kliszko, was the same individual who had earlier recommended that the Communist Party repress the production of Mickiewicz's Dziady at the theater in Warsaw.

On December 17, soldiers in Gdynia received orders to stop workers who were attempting to return to work and fired into the crowd of workers emerging from their trains. The protest movement then spread to other cities, leading to strikes and worker occupations of their places of work. The government mobilized 5,000 members of special squads of police and 27,000 soldiers equipped with heavy tanks and machine guns. Although the actual numbers are still in dispute, over 1,000 people were wounded, at least 40 were killed, and 3,000 were arrested. Professor Norman Davies (1982, p. 591) reported that "The Military Training Center in Slupsk was burned to the ground. Demonstrators were crushed by armored vehicles.... In all, some one hundred people were killed." The government falsely reported that only six people were reported dead. In order to avoid further troubles, the government ordered all those who perished to be buried overnight. Interestingly, in Gdansk, a 27-year-old electrician and activist at the Lenin Shipyards by the name of Lech Walesa was named by the workers to a strike committee.

\subsection{Edward Gierek}

The events of 1970 led to the dismissal of Gomulka as First Secretary of the Polish Communist Party at the Seventh Plenum of the Central Committee and the rise of Edward Gierek as leader of the Polish Communist Party. Gierek was initially hailed as an economic reformer (although he had little formal economic training) and champion of Polish workers, mainly because of his background as a mining technocrat in Silesia where he had supported generous wage increases and other benefits for Polish miners. Gierek was regarded by many Poles "as a pragmatic, non-ideological and economic progress-oriented manager." Gierek reaffirmed Gomulka's vision of a unique "Polish road to socialism."

Since the riots that brought down Gomulka were caused primarily by economic difficulties, Gierek immediately ordered a freeze in food prices for twelve months. He visited Gdansk and spoke directly with Polish 
workers, whom he "exonerated" for being the cause of unrest. Gierek promised economic reform, an end to compulsory deliveries of foodstuffs to the state by peasants and instituted a program to modernize industry and increase the availability of consumer goods. "Polish patriotism was reinforced by the rebuilding of the Royal Castle in Warsaw and contacts with Polish émigrés (Polonia) were both encouraged and strengthened" (Hunter \& Ryan 1998 , p. 30). The period 1970-1975 saw a dramatic increase in real wages by an average of 7.2 percent, a better supply of consumer goods, and the stabilization of prices for necessities.

However, contrary to what had become a "propaganda of success" and a certain nostalgia among the generation of his day, it can now be said that Gierek's policies were overall an "objective failure, leading the nation to the brink of economic disintegration and political collapse." Professor Sanford of the University of Bristol asserted: "The 1980 crisis had been caused primarily by the Gierek leadership's failure and authoritarian decisionmaking processes and by the over-ostentatious personal corruption of its cadres" (Sanford, 1982, p. 35). In addition, the reforms initiated by Gierek were largely based on massive foreign borrowing, not accompanied by systemic economic restructuring. Costly foreign licenses were obtained for Fiat automobiles, Jones cranes, Leland engines, Berliet buses, Grundig electronics, and Massey-Ferguson tractors. "The burden of the ever-increasing foreign debt became so severe that Poland was unable to produce enough exports to pay the interest on the various loans for the capital improvements" (Hunter \& Ryan, 1998, p. 31). The need for real reform was obscured by an investment boom and the perception of economic progress the country was experiencing in the first half of the 1970's.

The optimism that initially accompanied Gierek's rise to power would be short-lived. Goodwyn (1991, p. 125) stated: "The command economy lurched toward crisis, and the government tightened up on work norms throughout the society; the workers rebelled, and the party promised reforms; when changes did not materialize, the worker mobilization enlarged, and the party attempted new evasions." In a real sense, the 1970's can be termed as the period of "misused chances."

\subsection{June 1976}

Protests in Poland once again broke out after Gierek's Prime Minister, Piotr Jaroszewicz, announced the government's plan for a sudden increase in the price of many basic commodities, particularly foodstuffs (butter by $33 \%$, meat by $70 \%$, and sugar by $100 \%$ ). The protests began on June 24 and lasted until June 30. Large demonstrations and looting took place in Plock, in the Warsaw suburb of Ursus (the site of a major tractor factory), and particularly in Radom, where the Communist Party headquarters was burned to the ground. At the Lenin Shipyards in Gdansk, an occupation (sit-down) strike took place.

The protests were once again met brutally by the government, using tanks and helicopters. The authorities brought in ZOMO forces [in Polish, Zmotoryzowane Odwody Milicji Obywatelskiej- ZOMO], paramilitary-police formations organized during the communist era, to crush the protests. More than 1,000 people were jailed, beaten, and tortured. The plan for the price increase was shelved, but as de Weydenthal (1980, p. 191) noted: "It had become increasingly obvious that the man whose name had been associated in the minds of many with the exceedingly ambitious program of rapid industrialization and modernization of Poland's economy in the early 1970s had proved to be incapable of adjusting his views and of proposing new policies when the situation became more difficult."

\section{The Creation of KOR}

In retrospect, perhaps no single event stands as important as the founding of the Workers' Defense Committee, known as KOR in 1976 (generally, Zuzowski, 1994; Laba, 1991). The Workers' Defense Committee (in Polish: Komitet Obrony Robotników) was organized in September of 1976 by a group of Polish intellectuals in order to offer aid to workers who had been imprisoned and to their families after the June 1976 protests and the ensuing brutal government crackdown. The Committee was composed of fourteen and later 30 members drawn primarily from the "literary and technical intelligentsia" of Poland, including Antoni Macierewicz, Jan Litynski, Henryk Wujek, and Jacek Kuron. KOR was founded as a social organization or "civil society" outside of the Polish Communist Party expressly designed to engage Polish intellectuals in the workers' daily lives and struggles. "KOR hoped to demonstrate that unlike its inaction in previous crises, the intelligentsia would rally to the side of workers" (Hunter \& Ryan 1998, p. 39). A year later it was reorganized into the Committee for Social Self-Defence KOR (in Polish, Komitet Samoobrony Społecznej), but was still popularly referred to as KOR.

Professor Andrzej Walicki (1996, p. 520) regarded the emergence of KOR as a truly momentous event, providing Polish society with an alternative, an "organized and overt opposition, ... determined to organize social forces and mobilize them to exert pressure from without on the communist rulers...." KOR's Information Bulletin documented police fabrications and denounced the Polish legal system as illegitimate. KOR directed pleas to such outside organizations as Helsinki Watch and Amnesty International in order to focus attention on the plight of the "courageous workers" of Poland. KOR encouraged the creation of many quasi-public organizations such as the "Flying University" (in Polish, Towarzystwo Kursow Naukowych - TKN) (Bernhard, 1993), inspired the creation of the Committee for the Defense of Human and Civic Rights (in Polish, Ruch Obrony Praw Człowieka i 
Obywatela - ROPCIO), the Young Poland Movement (in Polish, Ruchem Młodej Polski - RMP), under Aleksander Hall, and a patriotic group called the Confederation for an Independent Poland (in Polish, Konfederacja Polski Niepodleglej - KPN), led by Leszek Moczulski.

In an important sense, by uniting Polish intellectuals and workers to the same cause, KOR may be seen as a precursor of and inspiration for the creation of Solidarity a few years later. "KOR became an overt antagonist to the Polish state and to the official unions" (Hunter \& Ryan, 1998, p. 40). The system was clearly beginning to crack. Economically, Poland was in dire straits. In 1979, the Polish economy shrank for the first time since World War II by 2.5 percent. Foreign debt reached around $\$ 18$ billion by 1980 . The standard of living for most Poles experienced a precipitous drop, accompanied by an average 120 percent rise in food prices and a 200 to 300 percent rise in the price of other consumer goods. John Darnton (1984, p. 40) wrote: There was a sense that events were spinning out of control and heading for disaster."

\section{Gdansk - 1980}

During the period of communism in Poland, the closed relationship between the state, the Communist Party, and the bureaucracy or nomenklatura became solidified. This relationship can be shown in the following diagram:

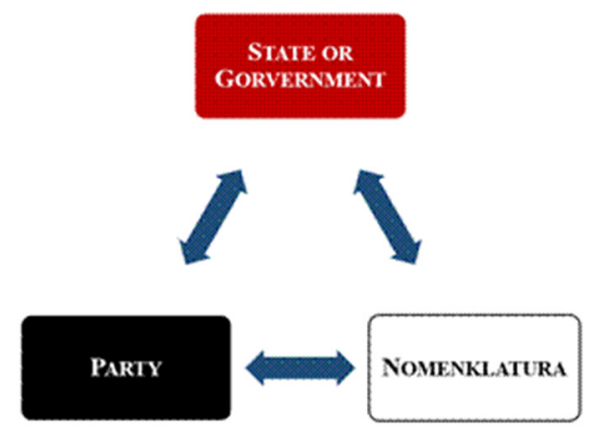

In this context, no outside group was permitted to penetrate this structure for fear that the entire system might collapse under its own weight.

Edward Gierek would continue in office until 1980, when another crisis hit Poland. What sparked the events of 1980? One was quite familiar. On July 1, 1980, the government once again announced increases in the prices of meat and meat products. "Workers reacted with shock and with a wave of strikes and work stoppages" (Hunter \& Ryan, 1998, p. 32). A second scenario proved to be more problematic.

Anna Walentynowicz, a diminutive 55-year old widow and shipyard crane operator at the Gdansk (Lenin) Shipyard, was fired for pro-union activities on August 7, 1980, just five months before she was due to retire. The decision to fire Walentynowicz enraged many of the workers at the Shipyard (14,000 in number), who staged a strike action on August 14 defending Walentynowicz and demanding her immediate rehiring. Through the efforts of Walentynowicz and a nurse at the factory, Alina Pienkowska, the strike was literally transformed into a movement involving other striking establishments seeking to exert an influence on management never before known in Communist Poland. Lech Walesa, who had been fired for union activities at the same shipyard in 1970, emerged as one of the key leaders of the protests. Under what became known as the "Interfactory Strike Committee" (in Polish, Międzyzakładowy Komitet Strajkowy - MKS) workers formulated a series of specific demands which had to be met if the workers were to return to work (Persky, 1981).

\subsection{The Twenty-One Demands (Appendix 1)}

The Interfactory Strike Committee compiled a list of Twenty-One Demands (Celt, 1980, p. 49) that would be served on the government's negotiators. These included:

i. Acceptance of free trade unions independent of the Communist Party and of enterprises, in accordance with convention No. 87 of the International Labor Organization concerning the right to form free trade unions.

ii. A guarantee of the right to strike and of the security of strikers.

iii. Compliance with the constitutional guarantee of freedom of speech, the press and publication, including freedom for independent publishers, and the availability of the mass media to representatives of all faiths.

iv. A return of former rights to: 1) People dismissed from work after the 1970 and 1976 strikes. 2) Students expelled because of their views. The release of all political prisoners, among them Edmund Zadrozynski, Jan Kozlowski, and Marek Kozlowski. A halt in repression of the individual because of personal conviction.

v. Availability to the mass media of information about the formation of the Inter-factory Strike Committee and publication of its demands.

vi. Bringing the country out of its crisis situation by the following means: a) making public complete 
information about the social-economic situation. b) enabling all social classes to take part in discussion of the reform programme.

vii. Compensation of all workers taking part in the strike for the period of the strike.

viii. An increase in the pay of each worker by 2,000 złoty a month.

ix. Guaranteed automatic increases in pay on the basis of increases in prices and the decline in real income.

x. A full supply of food products for the domestic market, with exports limited to surpluses.

xi. The introduction of food coupons for meat and meat products (until the market stabilizes).

xii. The abolition of commercial prices and sales for Western currencies in the so-called internal export companies.

xiii. Selection of management personnel on the basis of qualifications, not party membership, and elimination of privileges for the state police, security service, and party apparatus by equalization of family allowances and elimination of special sales, etc.

xiv. Reduction in the age for retirement for women to 50 and for men to 55, or (regardless of age) after working for 30 years (for women) or 35 years (for men).

xv. Conformity of old-age pensions and annuities with what has actually been paid in.

xvi. Improvements in the working conditions of the health service.

xvii. Assurances of a reasonable number of places in day-care centers and kindergartens for the children of working mothers.

xviii. Paid maternity leave for three years.

xix. A decrease in the waiting period for apartments.

$\mathrm{xx}$. An increase in the commuter's allowance to 100 złoty.

xxi. A day of rest on Saturday. Workers in the brigade system or round-the-clock jobs are to be compensated for the loss of free Saturdays with increased leave or other paid time off.

The most important and controversial of these demands were points one and two-unprecedented rights in a communist country and a direct challenge to the existence of communism and the supremacy of the Communist Party in Poland.

\subsection{Solidarity Emerges}

Solidarity (in Polish, Solidarność) formally emerged on August 31, 1980 in Gdansk at the Lenin Shipyards when the communist government of Poland signed an agreement with the strike committee. Later, on September 17, 1980, over 20 Inter-Factory Founding Committees representing various free trade unions across Poland merged at a congress into a central national organization, NSZZ Solidarity (in Polish, Niezależny Samorządny Związek Zawodowy - "Solidarność").

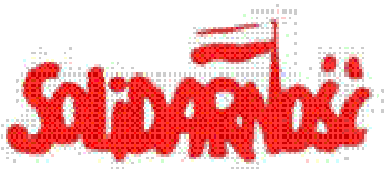
Solidarity was officially registered by the Polish government as a legal organization on November 10, 1980.

By its registration, Solidarity became the first truly independent organization (and independent trade union) in a communist country that was organized outside of and not controlled by a communist party. Its membership reached 10 million Polish workers by the time of its 1981 Congress - or one third of the total working-age population of Poland.

In the outstanding film "We've Caught God By the Arm” (2010) Zbigniew Bujak, a leader of the Solidarity Movement at the Ursus Tractor Factor in Warsaw, noted that in the 1980s, Solidarity was transformed from a union into a social movement, explicitly formed in order to advance the cause of workers' rights, using the methods of civil resistance that had been perfected by Mahatma Gandhi and Martin Luther King, Jr..

\subsection{Towards Martial Law}

The Polish government understood all too well that Solidarity posed a mortal threat to its continued existence (generally Sanford, 1982; 1984). Most especially between October and December 1981, tensions grew as the economy further deteriorated. The government reverted to its old form, attacking "antisocialist" elements in Solidarity and breaking many parts of the August 1989 agreement. In October, the government announced plans for price hikes for food and tobacco products. More than 300,000 workers engaged in a series of wildcat strikes. Industrial production plunged an additional 15 percent and exports declined by 25 percent. A government spokesman stated: "Poland could easily break apart because there is no government or Communist Party structure left" (Hunter \& Ryan, 1988, p. 55, citing World Gram, 1982, pp. 33-34). It also appears that from the outset that the Soviet Union was adamant that Solidarity had to be "summarily repressed." Reports from a Polish army officer, Colonel Ryszard Kuklinski, who was operating as a CIA mole in the Polish military, made it clear that at least on two occasions-December 1980 and March 1981 - the Soviet Union was poised on the brink of direct military intervention (see generally Kuklinski, 1987, pp. 3-57). On the early morning of December 13, 1981, General Wojciech Jaruzelski, who had succeeded Gierek, addressed the nation in order to justify an action, which by all measures, had amounted to a "lightening military coup": 
"Today I address myself to you as a soldier and as the head of the Polish government. I address you concerning extraordinarily important questions. Our homeland is at the edge of an abyss. The achievements of many generations and the Polish home that has been built up from the dust are about to turn into ruins. State structures are ceasing to function. Each day delivers new blows to the waning economy.

The atmosphere of conflicts, misunderstanding, hatred causes moral degradation, surpasses the limits of toleration. Strikes, the readiness to strike, actions of protest have become a norm of life. Even school youth are being drawn into this. Yesterday evening, many public buildings remained seized. The cries are voiced to physical reprisals with the 'reds', with people who have different opinions.

The cases of terror, threats and moral vendetta, of even direct violence are on the rise. A wave of impudent crimes, robberies and burglaries is running across the country. The underground business sharks' fortunes, already reaching millions, are growing. Chaos and demoralization have reached the magnitude of a catastrophe. People have reached the limit of psychological toleration. Many people are struck by despair. Not only days, but hours as well are bringing forth the all-national disaster.

Citizens!

The load of responsibility that falls on me on this dramatic moment in the Polish history is huge. It is my duty to take this responsibility - concerning the future of Poland, that my generation fought for on all the fronts of the war and for which they sacrificed the best years of their life. I declare, that today the Military Council of National Salvation has been formed. In accordance with the Constitution, the State Council has imposed martial law all over the country. I wish that everyone understood the motives of our actions. A military coup, military dictatorship is not our goal.

In longer perspective, none of Poland's problems can be solved with the use of violence. The Military Council of National Salvation does not replace constitutional organs of power. Its only purpose is to keep the legal balance of the country, to create guarantees that give a chance to restore order and discipline. This is the ultimate way to bring the country out of the crisis, to save the country from collapse.

I appeal to all the citizens. A time of heavy trials has arrived. And we have to stand those in order to prove that we are worthy of Poland.

Before all the Polish people and the whole world I would like to repeat the immortal words: Poland has not yet perished, so long as we still live!"

Martial Law lasted officially from December 1981 to July 1983 and was followed by several more years of political repression, internments of many Solidarity leaders, and economic stagnation. Economic reforms were proposed but did little to revive the Polish economy. During the period of Martial Law, the United States (with the strong support of President Reagan), in many cases in consort with the AFL-CIO, provided significant financial support to an underground Solidarity. Some have estimated that the support was as much as 50 million US dollars. One of the authors participated in more than one of these transfers during this period while on "academic" visits to Poland. The Polish Catholic Church also aided Solidarity during and after Martial Law, although ironically, the hierarchy of the Church was at the same time seeking to normalize relations (as far as possible) with the regime in order to seek certain privileges and benefits for the Catholic Church that were not available throughout the Soviet sphere. Their role during this period has been subjected to some negative commentary and serious discussion.

One of the most important events during the period involved a Roman Catholic priest, Fr. Jerzy Popiełuszko, who regularly offered masses for Polish workers and who increasingly became a thorn in the side of Polish authorities. "Fr. Jerzy," as he was called, was murdered by three agents of the Security Service of the Ministry of Internal Affairs (in Polish, Służba Bezpieczeństwa) on October 19, 1984. Lech Walesa spoke at the memorial following the funeral mass, which was attended by an estimated 350,000 persons. His eloquence may never again be matched: "The entire life of this good and courageous man, this extraordinary worker priest, pastor and leader of the national cause, bears witness to the unity of peace and social justice for our country. Solidarnosc lives on, Father Jerzy, because you gave your life for us" (Walesa, 1987, p. 306). For many Poles, the murder of Father Popieluszko marked the end of any thinking that an accommodation might be reached with the regime.

\section{Solidarity Takes Command}

The period following the lifting of Martial Law marked a time in which the government was unable to resolve the twin crises of a deteriorating economy and the foreign debt trap. Polish workers faced poor housing conditions, a demoralized system of education, increasing shortages, and a collapsing health care system (Hirszowicz, 1986). Poland also experienced another "great migration," as many young intellectuals, engineers, scientists, doctors, and other professionals opted to leave Poland because of "limited options and opportunities" (Hunter \& Ryan, 1998, 
p. 67). Many chose to emigrate to the United States.

A rash of new strikes once again enveloped Poland in 1988, including two rounds of industrial strikes centered in the Lenin Shipyards in Gdansk in May and August. The government faced a stark reality: It had no real choice to resolve the crisis other than to open talks with Solidarity. Once again, Lech Walesa emerged as the leader of the opposition. Round Table talks between the government and the Solidarity-led opposition, which unofficially included representatives of the Polish Catholic Church, led to the re-legalization of Solidarity, an end to the crippling strikes, and to semi-free elections in June of 1989 in which the Communist Party suffered a humiliating defeat by a margin of more than ten to one. Solidarity captured all of the available contested seats in the lower house and 99 out of the 100 seats in the Senate.

Despite having guaranteed its continued domination in the Polish Parliament (Sejm) by rigging the number of seats that would be available for democratic elections, by the end of August, General Czeslaw Kiszczak, Jaruzelski's designated Prime Minister, was unable to form a government, as two former puppet allies of the government refused to offer their support. Jaruzelski once again had no choice. A Solidarity-led coalition government was formed with Tadeusz Mazowiecki, as a representative of a small "Catholic" party in the Sejm, as Prime Minister. Mazowiecki was a Polish author, journalist, philanthropist, and Christian-democratic politician. Mazowiecki became the head of Warsaw chapter of the Club of Catholic Intelligentsia (KIK) and became known as one of the best-known Polish dissidents. Although not a member of the KOR, Mazowiecki supported it on numerous occasions, notably in the aftermath of the June 1976 protests that had broken out in Radom and Ursus (Friszke, 1994).

The Mazowiecki government faced a desperate situation. Production had stagnated further; budget deficits reached 60 percent of total expenditures; inflation rose from 60 percent in 1988 to 90 percent in July 1989-by August, inflation was running at 700 percent on an annual basis; foreign debt service was suspended due to a lack of convertible currencies. As Hunter and Ryan (1998, p. 74) wrote: "When Jaruzelski asked Tadeusz Mazowiecki to become Prime Minister and to form a coalition government, he was offering Mazowiecki no prize, only problems." The new government set on a bold course for reviving the economy under the direction of Deputy Prime Minister and Minister of Finance Leszek Balcerowicz, in a program that became known as "Shock Therapy."

Two overriding considerations governed the planning process: A market economy was preferred over a centrally planned economy and a private enterprise market economy would be preferred over "market socialism." Changes would be made quickly in a relatively short 3 to 4-month period.

\subsection{Solidarity's Economic Program}

The process of economic transition in Poland involved the interplay of several factors (adapted from Hunter \& Ryan, 1998). At its core, economic transition involved liberalizing economic activity, prices, and market operations; reallocating resources to produce their "best and highest use"; guaranteeing market stabilization; achieving effective enterprise management; imposing so-called "hard budget" constraints; and, perhaps most importantly, establishing an "institutional and legal framework to secure property rights, the rule of law, and transparent marketentry regulations" (generally, Kabir, 2010).

In Poland, the process was advanced through the creation and implementation of what became known as the Balcerowicz Plan (Sachs, 1993; Balcerowicz, 1995; Sowada, 1995; adapted from Hunter \& Ryan, 2000). The process of economic transformation in Poland has been quite instructive and has provided a more general model for other Central and Eastern European transition economies. The Plan was conceived by the then Minister of Finance and Deputy Prime Minister Leszek Balcerowicz and his team of national, "Polonia," and international advisers.

The "Balcerowicz Team" consisted, among others, of Marek Dabrowski, later deputy in the Ministry of Finance; Stefan Kawalec, first chief adviser, responsible for financial institutions; Janusz Sawicki, responsible for foreign debt negotiations; Andrzej Podsiadlo, who oversaw state enterprises; and Grzegorz Wojtowicz, first deputy chairman of the Polish National Bank, and its chairman in 1991. All were graduates of the Faculty of Foreign Trade of the Central School of Planning and Statistics in Warsaw, Poland's premier school for state planning and for producing "policy experts." Wojciech Misiag and Ryszard Pazura were also deputies in the Ministry of Finance. In addition, the team included numerous foreign advisers-Jeffrey Sachs, David Lipton, Wladyslaw Brzeski, Stanislaw Gomulka, Jacek Rostowski, and Stanislaw Welisz — and Polish ones-Karol Lutkowski, Andrzej Bratkowski, Antoni Kantecki, Adam Lipowski, Andrzej Parkola, and Andrzej Ochocki. Many of the foreign advisers were of Polish origin—so called Polonia academics.

Balcerowicz himself was a professor of economics at the Warsaw Institute of Economics. He had graduated from the Faculty of Foreign Trade at The Warsaw Planning and Statistics (now the Warsaw School of Economics), Poland's elite center of training for economists and future members of the Polish academic and professional bureaucracy. Between September 1972 and January 1974, Balcerowicz studied business administration, specializing in economics, at St. John's University. In 1974, he returned to Poland to receive his doctorate in 1975. In 1978, Balcerowicz organized a "think tank" from which proposals would come that would shape the program 
of economic reform

The program was based on five philosophical pillars of economic transformation:

- Rapid transformation of the monocentric system of state central planning into a private functioning market economy;

- Liberalization of economic functions, especially in relation to foreign trade and foreign direct investment;

- Privatization of state-owned-enterprises (SOEs) (Ryan, Hunter, \& Nowak, 1995; Hunter \& Ryan, 2004);

- Construction of an effective social safety net; and

- Mobilization of international financial assistance to support the process (Hunter \& Ryan, 2009; Fafara \& Kleczkowska, 2015).

Fafara and Kleczkowska (2015, p. 60) point out that the Balcerowicz Plan was an "ambitious process that enabled a significant shift in the economic and social landscape through the introduction of fundamental changes in the Polish legal system." They describe the eleven legislative acts which brought "wide ranging and fundamental changes to the Polish legal system" and make a more general point that "successful transformation of the state's regime in post-soviet countries depended not only on political changes, but also on effective economic reforms."

On the political side, a bargain was struck: "Your President, Our Prime Minister" (Domber, 2014). General Jaruzelski would remain as President and Mazowiecki, guided by Lech Wałęsa, would serve as Prime Minister. The bargain did not hold very long as Solidarity (under Walesa) moved to take full political power in Poland, citing the illegitimacy of continuing General Jaruzelski as President. Speaking at a meeting of the Warsaw Civic Committee, Walesa said: "A president of the past, a 35 percent prime minister- is this democracy?" (Hunter \& Ryan, 1998, p. 244, note 49, quoting Gazeta International, 1990).

In December 1990, Lech Walesa was elected President of Poland, defeating his former friend and ally, Tadeusz Mazowiecki, who failed to make the second round of the election. The presidential election resulted in what has been termed as the "War at the Top" in Solidarity ranks, reminiscent of the worker (Walesa) intelligentsia (Mazowiecki) split of pre-1980. Unfortunately for many, Solidarity and President Walesa became heavily involved in the minute details of Polish politics. Walesa proved "very difficult" to deal with through a succession of prime ministers and governments: [Bielecki, January-December 1991; Olszewski, December 1991May 1992; Suchocka, July 1992-October 1993; Pawlak, September 19923-February 1995; Oleksy, March $1995-$ January 1996] (Sabbat-Swidlicka, 1993). Then, almost unbelievably, Walesa was defeated for re-election in 1995 by a former or post-communist Aleksander Kwasniewski, who had been General Jaruzelski's chief negotiator at the 1989 Round Table. By 1995, many Poles believed that Walesa had become just another meddling politician and had lost his Solidarity roots as a champion of the Polish working class.

Kwasniewski was most successful in appealing to those who had suffered the greatest from the economic transformation and who may be considered as "losers" in the transformation process. These included residents of small towns and villages, and Polish workers who experienced high rates of unemployment and falling incomes. Many of these workers were employed in state-owned firms, in declining industries such as mining, metallurgy, shipbuilding, or other heavy industries, and who had ironically formed the backbone of the Solidarity Movement in 1980-1981. In contrast, many Poles saw "winners" in the new economy to be the former members of the nomenklatura who reappeared "sporting Western business suits and Western business attitudes," gaining control of newly privatized enterprises, often by exploiting "their enormous contacts made during the days of state socialism" (Hunter \& Ryan 1998, pp. 13, 191; generally Hunter \& Ryan, 1991).

In retrospect, the Presidential election of 1995 may have been a watershed moment for Poland. It seemed that even by 1993 society had reached what had been termed as the "barrier of social endurance" as Solidarity was defeated in the Parliamentary elections. Hunter and Ryan (1998) reported that "Calmness, discipline, and sacrifice characterized the early months of the Mazowiecki government after the introduction of the Balcerowicz Plan. Initial positive acceptance was widespread." However, in a short period of time, social tensions were once again on the rise; unions threatened strikes and farmers staged a nationwide two-hour blockade of Polish highways. By December of 1990, unemployment reached between 1.3 and 2 million Poles. Support for the program of "shock therapy" experienced a decided downturn in public enthusiasm, falling from 45 percent in October 1989 to about 20 percent in 1991. While Walesa had been elected President in 1990, his defeat just five years later signaled that the Polish people were unhappy with the choices that had been made and the progress that still eluded them.

President Walesa proved to be an especially bitter loser. When Kwasniewski was inaugurated as president on December 23, 1995, Lech Walesa refused to attend the ceremony.

"Solidarity," as a distinct political party, never again enjoyed wide electoral support. It won only 5 percent of the vote in the parliamentary elections of 1993. An explicit political arm of Solidarity was founded in 1996 as Solidarity Electoral Action (in Polish, Akcja Wyborcza Solidarność-AWS). AWS was successful in the parliamentary election in 1996 but was defeated in the 2001 elections. Currently, as a political party, Solidarity has fewer than 400,000 "official" members (there is really no way to be sure that this count is accurate) but has little influence on modern Polish politics as an independent political entity. 


\section{Part II- A Contemporary View}

\section{Solidarity's Long Shadow (adapted from Hunter, 2019)}

Despite its absence as a distinct political party, many of Poland's contemporary political parties claim strong roots in the Solidarity Movement. Two in particular merit attention: Law and Justice (in Polish: Prawo $i$ Sprawiedliwość- PiS) and Civic Platform (in Polish: Platforma Obywatelska- PO). Both share what would be generally characterized as a "right of center" position in Polish politics, but view economics, politics, and culture in very different ways.

PiS was founded in 2001 by the Kaczyński twins, Lech and Jarosław, both veterans of the Solidarity Movement, as a conventional centrist and Christian democratic party. It was originally formed from part of the Solidarity Electoral Action (AWS). PiS won the 2005 parliamentary election, while Lech Kaczyński won the presidency. PiS formed a coalition with the far-right League of Polish Families (in Polish, Liga Polskich Rodzin) and populist Self-Defence of the Republic of Poland (in Polish, Samoobrona Rzeczpospolitej Polskiej- SRP). Jarosław Kaczynski served as Prime Minister, before calling elections in 2007, in which the party came in second to Civic Platform (PO). In the 2007 parliamentary elections, PiS lost most of the more moderate electorate and turned to nationalism and populism instead. Several leading members, including President Lech Kaczyński, died in a plane crash in 2010 while en route to a memorial ceremony for the more than 14,000 Polish officers, soldiers, and others who had been murdered by the Soviet NKVD (Secret Police) in the spring 1940 (including the father of Anna Walentynowicz), in the Katyn Forest (Cienciala, et al., 2008). This tragedy further fueled PiS's move towards nationalism, populism, Euroskepticism, and a decidedly anti-Russian stance. Most especially since 2010, PiS has embraced economic interventionism, while maintaining a socially conservative stance in consort with more traditional elements of the Polish Catholic Church

PiS has heavily criticized Lech Walesa in stark personal terms and the policies of Minister Balcerowicz as having made Poland subservient to foreign business interests and foreign ownership. PiS has emerged today as Poland's leading political grouping, occupying the Presidency and holding a strong majority in the Parliament. The Polish American Journal (2018) described the current political situation as follows: "Poland's ruling conservative Law and Justice (PiS)... appeals to those in poor and rural communities where its generous social policies, anti-immigrant sentiment, skepticism of the European Union, and message of national pride steeped in conservative values...."

Their main opponent, the Civic Platform or PO, is described as appealing to "the more liberal, pro-European electorate." PO enjoys strong electoral support in "Warsaw, Krakow, Wroclaw, Gdansk, Lodz, and other urban areas" (Hunter $(2019$, p. 6). Civic Platform is liberal in the sense that it has generally followed the liberal approach to economics embodied in the Balcerowicz Plan; and yet is conservative in that it embraces traditional Polish social views, but perhaps in a less severe stance than PiS in Poland. Civic Platform came to power following the 2007 general election as the major coalition partner in Poland's government, with party leader Donald Tusk serving as Prime Minister of Poland. Tusk was re-elected as Prime Minister in the 2011 general election but stepped down three years later to assume the post of President of the European Council. Tusk's successor, Ewa Kopacz, led the party in the 2015 general election but was defeated by the PiS.

Ost (2018, p. 113) describes the situation in slightly different terms: "Labor support breaks down along three lines, with industrial labor mostly aligned with PiS, white collar labor (in education and health) mostly opposed, and the marginalized small-city precariat [people whose employment and income are insecure] being mobilized by PiS, but also finding a place in explicitly fascist parties further to the right. Left alternatives, weakened due to the collapse of class discourse, are slowly reemerging, but the Right will likely command more labor support for the near future." PiS was also successful in winning the presidential elections in 2015, when current President Andrzej Duda defeated incumbent President Bronislaw Komorowski in an upset, giving PiS full control of the government (Ost, 2018).

In taking power, PiS launched a program specifically designed to "regain control and revitalize the country's economy which has long been plagued by foreign domination..." (Strybel, 2017, p. 2). PiS ran on a platform calling for higher taxes on foreign-owned businesses and for curtailing the country's reliance on foreign capital, which PiS leadership asserted had made Poland into no more than a "vassal state." PiS maintained that the changes that had occurred in Poland since 1989 — most especially those carried out under the Balcerowicz Plan — had done little to return economic sovereignty to Poland following 123 years of foreign Partition, a difficult interwar period, and nearly 45 years of "communist misrule and mismanagement" (Strybel, 2017).

The isolationist sentiments voiced by PiS, returning to a theme often heard in the early days of the transition"Polska Dla Polakow" (Assimakopoulos, Baider, \& Millar, 20917)—were viewed by its supporters as an attempt to reintroduce Poland's national sovereignty over its economic future (Golebiowska, 2014). For others, the tone was more ominous.

The criticism voiced by PiS was direct and pointed: Instead of concentrating on rebuilding Poland's economic base from within by restructuring and revitalizing Poland's industrial base, PiS argued that successive Polish governments in the twenty five years after 1989 had engaged in a program of selling-off important Polish assets- 
often for a quick infusion of cash which was used politically to bolster Poland's budget.

PiS, along with other critics (many from veterans of the Solidarity Movement), argued that the initial push towards removing state control of the economy (generally, Trupiano, 1993), now known derisively as "spontaneous privatization" (Polishchuk, 1995; generally Hunter \& Ryan, 2008), was often no more than the theft of public assets, or simply kleptocracy (Moorman, 2018), accomplished through "crony capitalism" and insider trading, which favored members of the former nomenklatura (Dubrow, 1997; Tyminiski, 2017), Poland's discredited communist bureaucratic class.

The Sarmatian Review (2016) encapsulated many of these criticisms and reported the following aspects of foreign investment in Poland:

- The percentage of factories engaged in manufacturing in Poland owned by foreign entities in 2016 had reached more than $50 \%$;

- More than $60 \%$ of Poland's banks were at one time foreign owned - although the ratio is now nearer to $50 / 50$;

- 90 billion zlotys (or about 25 billion dollars) were transferred from Poland "abroad" each year because of the structure of ownership of Polish enterprises.

Critics also pointed out that in the past quarter century, some of Poland's former "banner" state-ownedindustries (SOEs) such as mines, Baltic ship building facilities (the most prominent example being the former Lenin Ship Yard in Gdansk) and other examples from Lodz and Katowice (Rytelewska-Chilczuk, 2016), and steel making facilities (for example, Nowa Huta) were closed or employment significantly scaled back when the government failed to directly intervene in their deteriorating finances or was unable to procure a foreign buyer willing to invest the sums necessary to modernize operations in order to assure that the businesses would remain open. Rytelewska-Chilczuk (2016, p. 231) noted that this "post-industrial identity is often perceived as shameful marks of degraded landscape, abandoned factories and industrial plants." As a result, tens of thousands of Polish workers became permanently unemployed. At the same time, the economy became dominated by foreign-owned banks (see Allen, Jackowicz, Kowalewski, \& Kozlowski, 2017), foreign-owned retail giants, and assembly plants controlled by foreigners, which in turn funneled most of their profits abroad to the benefit of foreign investors.

Since 2015, under the direction of Deputy Prime Minister Mateusz Morawiecki, who now serves as Prime Minister, Poland would turn decidedly inwardly and would implement a series of restrictions on business and taxes on foreign-dominated economic sectors, including banking and insurance, energy, and healthcare. These restrictions and taxes have dampened some investor enthusiasm and have increased the government's ownership of some firms - reversing privatization efforts in certain economic sectors (Jasiecki, 2017). The government reduced the retirement age for women to 60 years of age in 2016 (Goettig, 2017), placing additional burdens on the state budget, which had a projected deficit of $2.9 \%$ of GDP, only slightly below the EU's Maastricht Treaty $3.0 \%$ limit. The government projected that the economy would grow 3.8 per cent and the inflation rate would be 2.3 percent in 2019 (Kozlowska, 2018). Poland's budget deficit was set at 1.8 per cent of GDP. The projected budget for 2020 announced in late April of 2019 predicts that GDP growth to slow to 3.7\% in 2020 from $4.0 \%$ in 2019. Inflation is to jump to $2.5 \%$ in 2020 from the $1.8 \%$ forecast for 2019. In 2020, the government deficit is to be $0.9 \%$ of GDP in 2020, down from the actual 1.7\% in 2019 (Central European Financial Observer, 2019).

\section{The Morawiecki Plan}

The strategy adopted by PiS is embodied in the Morawiecki Plan, named for then Deputy Prime Minister Mateusz Morawiecki (Mroczkowski \& Miller, 2017). The Plan represented a sharp departure from the approach of the Balcerowicz Plan. Morawiecki, whose father was a prominent Solidarity activist and founder of "Fighting Solidarity," noted: "We have been in this [economic] model for 27 years. We have reached the trap of dependent development. To a huge extent we are dependent on foreigners" (Foy, 2016).

The program would address deficiencies in the Polish economy through actions described as Minister Morawiecki's "five pillars of economic development of Poland":

- Reindustrialization - i.e., focusing on industries in which Poland can gain a competitive advantage and attract foreign investment;

- Development of innovative companies, which involves, among others, drawing up a Business Constitution designed to simplify regulations, help develop and launch innovative products, and raise spending on research and development;

- Raising capital for development - aiming for a significant increase in capital expenditure, and improved efficiency of institutions supporting investment; the establishment of the Polish Development Fund;

- Foreign expansion - support for Polish exports aimed at reaching new markets, conducting foreign trade missions, and developing a network of "economic diplomacy posts" throughout current and potential markets;

- Social and regional development - a proposal to create a comprehensive demographic program, the reform 
of the education system, and support for the development of Polish regions that had not reaped the benefit of prior development efforts (adapted from Borowski \& Jaworski, 2016).

In addition, Minister Morawiecki supported the creation of a "new spirit of Polish entrepreneurship," with an emphasis on fostering opportunities in economic sectors that would be export sensitive, and the creation of new Polish brands ("Polish Champions") which could compete worldwide with high-quality recognizable products, and which would assure the return of many of Poland's "best and brightest" who had emigrated in the search of economic opportunity in Western Europe, the United Kingdom, and the United States (Strybel, 2017).

The Morawiecki Plan, which has been termed Polonization, would include buying back businesses previously privatized. However, where the funds would come from to accomplish this objective remains to be seen. Poland is still a country that "lacks significant internal capital," although no longer "capitalists." A policy announced by the government to tax large, mainly foreign-owned retail chains and banks has been challenged by the European Union (Martewicz \& Krasuski, 2016; Foy, 2016). The tax on banks did not meet its expected target of 5.5 billion zl. and instead was projected to raise only 3 billion zl. in revenue. The tax on large retailers was questioned on grounds that it amounted to "unacceptable state aid for small Polish enterprises" and had to be shelved until a date in the future (Zygulski, 2016/2017). These policies have led to frequent clashes with Brussels and the European Union.

\section{The Current State of the Polish Economy}

There are several positive indicators in the economy (adapted from OECD, 2018).

- Strong growth, a booming labor market, and rising social transfers are underpinning rapid growth in consumption (Lewandowski \& Magda, 2018). More than 4,200 workplaces were created since January 2018, thanks to foreign investments in the country. According to data from PAIH, the Polish Investment and Trade Agency, the first four months of 2018 saw 19 investment projects with a total value of EUR 139 million being finalized. New jobs were created primarily in the field of business services, in the research and development sector, as well as in aerospace.

- Investments in business services (Kuznar, 2018), with a total value of EUR 149.09 million, accounted for nearly 36 percent of the total projects supported by PAIH. In total, PAIH is supporting 189 projects with a value of EUR 3.76 billion, which are set to create almost 40,500 jobs.

- The unemployment rate is at a record low level, standing at 3.8\% as of May 2019. Labor shortages are spreading, and there are some positive signs of increasing wages (G Suite, 2018). The labor market is expected to tighten even further (Emerging Europe, 2018), leading to somewhat faster wage and price inflation. In fact, "Every eighth business has been forced to retreat from planned investment because of a shortage of candidates" (Emerging Europe, 2018). After a severe contraction in 2016, the OECD (2018) projects that investment will recover, "driven by faster disbursements of EU structural funds, capacity constraints, and low real interest rates."

- New public benefits have helped to bring down poverty. Poverty and income inequality have fallen in Poland, and large "family benefits" introduced in 2016 have helped to bring down child poverty even further. The government has also announced that it intends to improve access to affordable childcare services (Heinen \& Wator, 2006). In order to reverse the trend towards a negative birth rate, plans have been announced to promote fertility in the context of very rapid aging population (Leszko, Zajac \& Lamparska, 2015).

\subsection{New Challenges}

What are some of the macro-challenges facing Poland today? Challenges persist in the Polish economy which include addressing deficiencies in its road and rail infrastructure and in its general business environment, a still rigid labor code, a slow moving commercial court system involved with enforcing commercial contracts, the existence of excessive government red tape and over-regulation, and a burdensome tax system, although Ernst \& Young (EY) (2017) reported that Poland passed a package of corporate income tax reforms that might "have a significant impact on the majority of companies operating in Poland."

In the long range, Poland must diversify its Poland's energy mix, strengthen investments in the "innovation economy," and bolster investment in research and development. In addition, Poland must continue to address a systemic "brain drain" of educated young Poles (more than 1.4 million, with 679,000 alone living in the UK), especially young health care professionals (Krajewski-Siuda, et al., 2008), to other EU member states (Sobczyk, 2010; Davies, 2011). Whitehead (2015) reports: "The Warsaw government's Powroty, or Returns, programme is aimed at persuading back the army of well educated and skilled workers who flocked to the UK when Poland joined the EU more than a decade ago." Demographically, "Poland faces contraction due to emigration, persistently low fertility rates, and the aging of the Solidarity-era baby boom generation" (CIA, 2017/2018).

On the other hand, the OECD (2018) reported that there is a risk that the "family-friendly benefits" introduced into Poland might induce less-skilled women to leave the labor market (Plomien, 2006) for longer periods after 
childbirth, shortening their contribution periods to an already strained pension system that itself is badly in need of reform (see Morgandi \& Bargu, 2018). Rutecka (2014) noted the "deepening deficit in the Social Insurance Fund, as did Kompa \& Witkowska (2015). Rutecka (2014) wrote: "The changes that have been introduced will not remedy it. Its main causes are demographic factors such as low birth rate, emigration, and increased life expectancy. Consequently, in the long run, without the support from the state budget, [there] may not be enough funds to pay pension benefits."

There is also a lack of organized out-of-the-home institutional care for the elderly which may be seen as another barrier to female employment and an improved quality of life for Polish seniors, although this change would require a major reordering of patterns in Polish society relating to the care of the elderly outside of the traditional home environment.

Raising Poland's capacity to innovate would ensure continued convergence to higher living standards. The OECD (2018) noted: "Poland's income convergence has mainly resulted from efficiency gains thanks to sectoral restructuring carried out with the active assistance of the Polish government and foreign technology absorption as a result of foreign direct investment." Because Poland's labor productivity is still $40 \%$ below the OECD average (OECD, 2018), Poland will need to strengthen its technology sector and its capacity for innovation.

Investment in research and development $(R \& D)$ is still weak which may hamper innovation in the Polish economy, especially in small and medium-sized enterprises (SMEs) (Dec \& Masiukiewicz, 2014; European Commission, 2018).

In its Strategy for Responsible Development (see Oleksiuk, 2017), developed by the Ministry of Economic Development in April 2016, the government announced plans to boost targeted R\&D tax incentives along with increasing public support for innovation in Small and Medium Enterprises (SMEs), further development of the venture capital market, and accelerated infrastructure development. However, many of these programs will remain largely dependent on the continued infusion of EU structural funds financing in both the long and short runs. Thus, cooperation with the European Union remains a critical component of future success.

\section{Concluding Comments: "Quo Vadis, Poland?"}

Not all Polish citizens are in tune with the policies of the PiS (e.g., Markowski, 2018). At the height of a constitutional crisis in January 2016, Standard \& Poor downgraded Poland's rating on the S\&P 500 from an Awith a positive outlook to a BBB + with a negative outlook (Business Recorder, 2016). Though the adjustment wasn't immense, it may speak volumes as to the direction in which the leadership of the country is driving the country. The Polish zloty dropped by $2.4 \%$, the biggest decline among emerging-market currencies, and in April 2016 the zloty hit its lowest mark in two months falling to 4.4275 per euro (Krasuski, 2016). [The current rate is 4.31834 per euro.] Despite the negative reactions from some of its neighbors (with the notable exception of Hungary), an outcry from many of its citizens, and even public rebuke from three past Polish Presidents (Cienski, 2016), PiS refused to back down. Anti-government demonstrations increased so much that a 2016 protest was the largest since 1989 when Poland broke from its communist past (Reuters, 2016). Far-right protests have broken out as well in support of PiS, in opposition to immigration, and against plans to create a restitution fund for Jewish victims of the Holocaust.

The recent controversy relating to alleged Polish participation in events of the holocaust (John, 2018), with a bill proposed by PiS calling for "three years in prison or a fine for accusing the Polish state or people of involvement or responsibility for Nazi occupation during World War II" has strained Polish relations throughout the world community. Some Poles are concerned that the government has been undermining democratic institutions, curbing democratic checks and balances, violating EU principles, and creating tension between the EU and its allies. Protests continued into 2018 and 2019 relating to actions taken by PiS concerning the Polish Supreme Court (Santora, 2018), which critics charged would result in "eroding the judiciary's independence, escalating a confrontation with the European Union over the rule of law and further dividing this nation."

Fomina and Kucharczyk (2016) noted that the 2015 victory of PiS marked the victory of a kind of "authoritarian populism" drawing on its power to "dismantle democratic checks and balances." They wrote: "The PiS's policies have led to intensifying xenophobia, aggressive nationalism, and unprecedented polarization that have given rise to social protest movements not seen in Poland since 1989."

With election looming in the fall of 2019, Pawlak and Jones (2019) noted that PiS has mounted a campaign to appeal to more educated urban voters "beyond their conservative rural base" ahead of a parliamentary election in the fall. Their objective may be to gain a large enough majority (two-thirds) to change the constitution and initiate "reforms" in the judiciary.

PiS is seemingly walking an electoral tightrope. It has employed generous social program and strong economic growth, while its "Euroskepticism," and "tough stance on immigration and embrace of traditional Catholic values" are designed to placate the interests of conservative voters. Can it keep its conservative base while broadening its appeal to a new generation of Poles who may be more interested in economic progress than in relitigating the ancient grudges of the past? 
One thing may be working in favor of PiS: The lack of coordination on the part of opposition parties. Polish opposition will most likely run in the upcoming general elections in three separate blocks: Koalicja Obywatelska (KO), which includes the largest opposition grouping consisting of Civic Platform (PO), the liberal Nowoczesna and Inicjatywa Polska, and local government representatives; Koalicja Polska, composed of the agrarian Polish Peoples Party (in Polish, Polskie Stronnictwo Ludowe - PSL); as well as a traditional leftist block including the post-communist Democratic Left Alliance (in Polish, Sojusz Lewicy Demokratyczne - SLD) (Warsaw Voice, 2019).

Whether the policies adopted by PiS will continue to have a "spill over" into economics and foreign investment is another matter. Until recently, there seemed to be a consensus about the path that Poland had chosen. Recent events have brought this consensus into doubt.

Did the emergence and victory make any difference for Poland? What may seem obvious is that the Poland of 2019-2020 has come through a long journey from its Solidarity roots. Even as the economy has flourished (Poland was the only member of the European Union not to suffer a recession in 2008-2009), politics is fractured, as long time allies still debate the efficacy of a plan developed thirty years ago in order to change Poland's economic system. PiS, although claiming string roots in Solidarity, has today rejected the core economic assumptions of the Balcerowicz Plan in favor of economic nationalism, Euroskepticism, and looking decidedly inwardly. Yet, ironically, nostalgia for the ideals of Solidarity and the ethos it captured in the summer of 1980 still remain especially strong in many elements of society seeking to find Poland's proper place in the modern world.

\section{References}

Allen, F., Jackowicz, K., Kowalewski, O., \& Kozlowski, L. (2017). Bank lending, crises, and changing ownership structure in Central and Eastern European countries. Journal of Corporate Finance, 42: 494-515.

Assimakopoulos, S., Baider, F., \& Millar, S. (2017). Analysis of online comments to news reports. Online Hate Speech in the European Union: 25-52.

Balcerowicz, L. (1995). Socialism, capitalism, transformation. New York: Central European Press.

Bernhard, M. (1993). The origins of democratization in Poland. New York: Columbia University Press.

Borowski, J. \& Jaworski, K. (2016). Morawiecki plan calls for robust local government investment. Financial Observer (June 4). Available: http://www.financialobserver.eu/wp

Business Recorder. (2016). Poland's constitutional crisis is credit negative: Moody's. Available: http://www.brecorder.com/world/global-business-a-economy/288614-polands-constitutional-crisis-iscredit-negative-moodys.html

Celt, E. (1980). Strikes taking on a political dimension: 47-ff. In Robinson, W.F. (ed.) August 1980: The strikes in Poland. Munich: Radio Free Europe Research.

Central European Financial Observer. (2019). Poland's macro assumptions for 2020 budget differ from convergence plan. Financial Observer (May 9). Available: https://financialobserver.eu/recent-news/polandsmacro-assumptions-for-2020-budget-could-differ-from-convergence-plan/

Central Intelligence Agency (CIA). (2017/2018). CIA factbook Poland. Available: http://www.factbook.org/factbook/pl.shtml

Cienciala, A., et al. (eds.) (2008). Katyn: A Crime without punishment. New Haven, Conn.: Yale University Press.

Cienski, J. (2016). Poland's PiS warns critics: We're not changing, get used to it. Politico (June 2). Available: https://www.politico.eu/article/jaroslaw-kaczynski-constitutional-tribunal-polands-pis-warns-critics-werenot-changing-get-used-to-it/

Darnton, J. (1980). “60 Days That Shook Poland.” New York Times (November 9), T10. Reprinted in Lineberry, W.P. (ed.). Poland. New York: H.W. Wilson.

Davies, C. (2011). "Poland struggles to reverse its brain drain." CNN.com (September 11). Available: www.cnn.com/2011/WORLD/europe/09/07/poland.return.migration/index.html

Davies, N. (1982). God's playground: A history of Poland. Vol. II, 1795 to the present. New York: Columbia University Press.

Dec, P. \& Masiukiewicz, P. (2014). "The support system for small and medium business: Case of Poland." Research in World Economy, 5(2): 150-158.

de Weydenthal, J.B. (1980). The end of the Gierek era: 191-212. In Robinson, W.F. (ed). August 1980: The strikes in Poland. Munich: Radio Free Europe Research.

Domber, G.F. (2014). Empowering Revolution: America, Poland, and the end of the Cold War. Chapel Hill, N.C.: University of North Carolina Press.

Dubrow, J.P. (1997). "Accounting for the difference: The fate of Polish nomenklaturas since 1989." Defense Technical Information Center (National War College) (January). Available: http://www.dtic.nil/dtic/tr/fulltext/us/a442044.pfd

Emerging Europe. (2017). "Polish labour market deficits are impacting." Available: http://emergingeurope.com/in-brief/polish-labour-market-deficits-are-impacting-all/

European Commission. (2018). "State Aid: Commission approves Polish investment aid to SMEs in the 
shipbuilding sector; opens investigation into Polish tax incentives for shipyards." Available: http://europa.eu/rapid/press-release_IP-18-242_en.htm

EY (Ernst \& Young). (2018). Doing business in Poland: Sectors. Available: https://www.ey.com/doingbusinessinpoland/sectors

Fafara, A. \& Kleczkowska, A. (2015). "How to attain the golden age- the role of the Balcerowicz plan in the successful transformation of Poland in the 1990s." Romanian Journal of Society and Politics, 10(2): 60-78.

Fomina, J. \& Kucharczyk, J. (2016). "Populism and protest in Poland.” Journal of Democracy, 27(4): 58-68.

Foy, H. (2016). "Poland vows to end free market approach despite gains." FT.com [Financial Times] (June 9). Available: http://www.ft.com/content/6a702384-2e49-11e6-bf8d-26294ad519fc

Friszke, A. (1994). Opozycja polityczna w PRL 1945-1980 [Political opposition in the PRP, 1945-1980] (in Polish). London: Aneks.

Gazeta International (1990): 1 (August 9).

G Suite. (2018). Poland average salaries \& expenditures. Available: http://www.worldsalaries.org/poland.shtml.

Goodwyn, L. (1991). Breaking the barrier: The rise of Solidarity in Poland. New York: Oxford University Press.

Goettig, M. (2017). "Polish cut in retirement age comes into force, bucking European trend." Reuters (October 1). Available: https://www.reuters.com/article/us-poland-pension/polish-cut-in-retirement-age-comes-intoforce-bucking-european-trend-idUSKCN1C60Z6

Golebiowska, E.A. (2014). The many faces of tolerance. New York: Routledge.

Heinen, J. \& Wator, M. (2006). "Child care in Poland before, during, and after the transition: Still a women's business.” Social Politics: International Studies in Gender, State and Society, 13(2): 189-216.

Hirszowicz, M. (1986). Coercion and control in communist society: The visible hand in a command economy. New York: St. Martin's Press.

Hunter, R.J. (2019). "Poland and FDI: Pathway to development or flashpoint to conflict within the European Union?" Global Journal of Economics and Finance, 3(1): 1-17.

Hunter, R.J. \& Ryan, L.V. (1991). "Uwaga (watch out!). Opportunities and pitfalls for an American doing business in Poland: The political and economic scene." The Polish Review, 36(3): 345-361.

Hunter, R.J. \& Ryan, L.V. (1998). From autarchy to market. Westport, Conn.: Praeger.

Hunter, R.J. \& Ryan, L.V. (2000). "The challenge of political and economic change in Poland and Central and Eastern Europe.” International Journal of Value Based Management, 13: 97-107.

Hunter, R.J. \& Ryan, L.V. (2004). "Privatization and transformation in Poland." The Polish Review, 49(3): 919943.

Hunter, R.J. \& Ryan, L.V. (2008). "A field report on the background and processes of privatization in Poland."

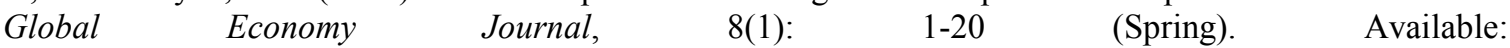
https://ideas.repec.org/a/bpj/glecon/v8y2008i1n5.html

Hunter, R.J. \& Ryan, L.V. (2009). "Poland in 1989: Enter Tadeusz Mazowiecki and the creation of the Balcerowicz plan." Research Journal of International Studies, 11: article 4. Available: https://www.researchgate.net/publication/ 292780073_Poland_in_1989_Enter_Tadeusz_Mazowiecki_and the creation_of_the-Balcerowicz-Plan.

Hunter, R.J., Ryan, L.V. \& Nowak, A. (1995). "Legal aspects of the transformation process in Poland: Business association forms." The Polish Review, 40: 387-407.

Hunter, R.J., Ryan, L.V., \& Shapiro, R.E. (2003). Poland: A transitional analysis. New York: PIASA Press.

Jasiecki, K. (2017). "The nature of capitalism in Poland: Controversy over the economy since the end of 2015: The prospects of business elites and employer associations." Corvinus Journal of Sociology and Social Policy, 8(3): 171-193.

John, T. (2018). "Poland just passed a holocaust bill that is causing outrage. Here's what you need to know." Time (online) (February 1). Available: https://casteddu17.wordpress.com/2018/02/01/new-top-story-from-timepoland-just-passed-a-holocaust-bill-that-is-causing-outrage-heres-what-you-need-to-know/

Kabir, T. (2010). "On privatization in economies in transition." Available: https://www.scribd.com/document/38992168/On-Privatization-in-Economies-in-Transition

Kompa, K, \& Witkowska, D. (2015). "Pension system in Poland: performance of pension funds." Estudios de Economia Aplicada [Studies in Applied Economics], 33(3): 965-984.

Kozlowska, K. (2019). "Poland: 2019 draft budget adopted." Central European Financial Observer (August 22). Available: https://financialobserver.eu/daily/poland-2019-draft-budget-adopted/

Krajewski-Siuda, K., et al. (2008). "Brain drain threat- Polish students are not satisfied with labor market for health professionals in Poland.” Journal of Public Health, 16(5): 347-351.

Krasuski, K. (2016). "Polish zloty's haven status just a memory as it lags every peer." Bloomberg (June 1). Available: $\quad$ https://www.bloomberg.com/news/articles/2016-05-01/polish-zloty-s-haven-status-just-amemory-as-it-lags-every-peer

Kuklinski, R. (1987). "Wojna z narodem widziana od srodka [The war with the nation seen from the inside]." 
Kultura: 3-57 (April).

Kuznar, A. (2008). "The effects of accession to the European Union for the competitiveness of Polish service sectors.” Available: https://www.researchgate.net/profile/Andzelika_Kuznar

Laba, R. (1991). The roots of Solidarity: A political sociology of Poland's working-class democratization. Princeton, N.J.: Princeton University Press.

Leszko, M., Zajac-Lamparska, L. \& Trempala, J. (2015). “Aging in Poland.” The Gerontologist, 55(5): 707-715.

Lewandowski, P. \& Magda, I. (2018). "The labor market in Poland, 2000-2016." IZA World of Labor: 1-9. Available: https://wol.iza.org/.../426/pdfs/the-labor-market-in-poland.pdf?v=1

Markowski, R. (2018). "Creating authoritarian clientelism: Poland after 2015." Hague Journal of the Rule of Law (online). Available: https://link.springer.com/content/pdf/10.1007/s40803-018-0082-5.pdf

Martewicz, M. \& Krasuski, K. (2016). "Poland takes aim at retailers with $\$ 485$ million tax plan.” Bloomberg.com (January 25). Available: http://www.bloomberg.com/news/articles/2016-01-25/poland-to-help-local-shopsas-new-tax-targets-bigger-retailers

Micewski, A. (1984). Cardinal Wyszynski: A biography. San Diego: Harcourt Brace Jovanovich.

Moorman, T.C. (2018). "Kleptocracy and foreign corruption manifesting in illicit financial flows." Journal of Financial Crime, 25(3): 681-701. Available: https://www.emeraldinsight.com/doi/abs/10.1108/JFC-022017-0008

Morgandi, M. \& Bargu, A. (2018). "Can mothers afford to work in Poland: Labor supply incentives of social benefits and childcare costs." World Bank Policy Research Working Paper No. WPS 8295. Available: http://documents.worldbank.org/curated/en126541515423428331.

Mroczkowski, T. \& Miller, M. (2017). "Envisioning smart development in Poland from a triple helix systems perspective: A critical assessment of the Morawiecki plan." Journal of the Knowledge Economy, 8(2): 513535 .

OECD. (2018). Economic survey of Poland 2018. Available: http://www.oecd.org/eco/surveys/economic-surveypoland.htm.

Oleksiuk, A. (2017). "Poland's responsible development strategy- challenges, reflections and remarks." EAEPE 2017 Online Proceedings, Corvinus University of Budapest. Available: https://www.researchgate.net/profile/Adam_Oleksiuk2/publication.

Ost, D. (2018). "Workers and t"he radical right in Poland." Workers and right-wing politics, 93: 113-124.

Pawlak, J. \& Jones, G. (2019). Poland's ruling nationalists seek to broaden appeal as election nears.” Reuters (July 27). Available: https://www.theguardian.pe.ca/news/world/polands-ruling-nationalists-seek-to-broadenappeal-as-election-nears-334180/

Persky, S. (1981). At the Lenin shipyard: Poland and the rise of the Solidarity trade union movement. Vancouver, B.C.: New Star Books.

Plomien, Ania. (2006). "From socialism to capitalism: Women and their changed relationship with the labor market in Poland," 247-274. In Blossfeld, H-P. \& Hofmeister, H. (eds). Globalization, uncertainty and women's careers: An international comparison. Cheltenham, UK: Edward Elgar Publishing.

Polish American Journal. (2018). Liberals keep control in big cities. December, 107(12): 1.

Polishchuk, L. (1995). "Robber barons and economic efficiency: The case of spontaneous privatization." Mathematical Social Sciences (Abstract), 30(3): 320.

Reuters. (2016). Thousands march in anti-government protest in Poland. June 8. Available: http://www.sbs.com.au/news/article/2016/05/08/thousands-march-anti-government-protest-poland

Rutecka, J. (2014). "The pension system after the changes of 2014." Social Insurance. Theory and Practice, 2: 27.

Ryan, L.V., Hunter, R.J., \& Nowak, A. (1995). “The zig-zag road to Polish privatization,” 1079-1107. In K. Fatemi \& Nichols, S.E.W. (eds). International business in the $21^{\text {st }}$ century. International Finance Association Working Papers.

Rytelewska-Chilczuk, N. (2016). "The identity of post-industrial cities on the example of Gdansk, Lodz and Katowice. Pisma Humanistyczne" [Humane Letters], 14: 231-248.

Sabbat-Swidlicka, A. (1993). "Poland: A year of three governments." Munich: Radio Free Europe/Radio Liberty, 2(1): 102-107.

Sachs, J. (1993). Poland's jump to a market economy. Cambridge, Mass.: MIT Press.

Sanford, G. (1982). "The response of the Polish communist leadership to the continuing crisis: Personnel and policy changes." In Woodall, J. (ed.). Policy and politics in contemporary Poland. London: Frances Pinter.

Sanford, G. (1984). "The Polish communist leadership and the onset of the state of war." Soviet Studies, 36(4): 494-512.

Santora, M. (2018). "Poland purges supreme court, and protestors take to streets." New York Times (online) (July 3). Available: https://www.nytimes.com/.../europe/poland-supreme-court-protest.html

Sarmatian Review. (2017). Sarmatian review data: The flip side of foreign investment in Poland (January): 2050. 
Sobczyk, M. (2010). "Poland loses 1.4 million people to brain drain.” Wall Street Journal (online) (September 24). Available: https://blogs.wsj.com/.../24/14-million-poles-leave-in-eu-brain-drain

Sowada, C. (1995). “The stabilization program: Balcerowicz plan.” Available: https://www.researchgate.net/ publication/316162076_The stabilization_program_Balcerowicz-Plan

Strybel, R. (2017). "Can the Morawiecki plan revitalize Poland's economy?” Polish American Journal (January): 2 .

Trupiano, G. (1993). "Privatization in Eastern Europe.” Atlantic Economic Journal, 21(1): 27-36.

Tyminiski, M. (2017). "Local nomenklatura in communist Poland: The case of the Warsaw Voivodship (19561970)." Europe Asia Studies, 69(12): 1-19.

Walesa, L. (With Marek Zaleski) (1987). A way of hope: An autobiography. New York: Henry Holt and Co.

Walicki, A. (1996). "Totalitarianism and detotalitarianism: The case of Poland." The Review of Politics: 58(3): 505-529.

Warsaw Voice. (2006). Investors praise Poland (February 5): 30-31.

Warsaw Voice. (2019). Opposition still divided. (July 28). Available: http://www.warsawvoice.pl/WVpage/pages/ article.php/45686/news

Weschler, L. (1982). Solidarity: Poland in the season of its passion. New York: Simon and Schuster.

Whitehead, T. (2015). "Campaign to lure Poles back home amid fears of brain drain to Britain." Telegraph (March 6). Available: https://www.telegraph.co.uk/news/uknews/immigration/11454795/

World Gram. (1982): 33-34

Zuzowski, R. (1994). Political dissent and opposition in Poland: The workers' defense committee "KOR." Westport, Conn.: Praeger.

Zygulski, W. (2016/2017). "Poland's conservative government one year on.” Warsaw Voice (Winter): 6-7.

Film:

"We’ve Caught God by the Arm.” (2010). Facing History and Ourselves. Brookline, Mass.

\section{Appendix I - The 21 Demands}

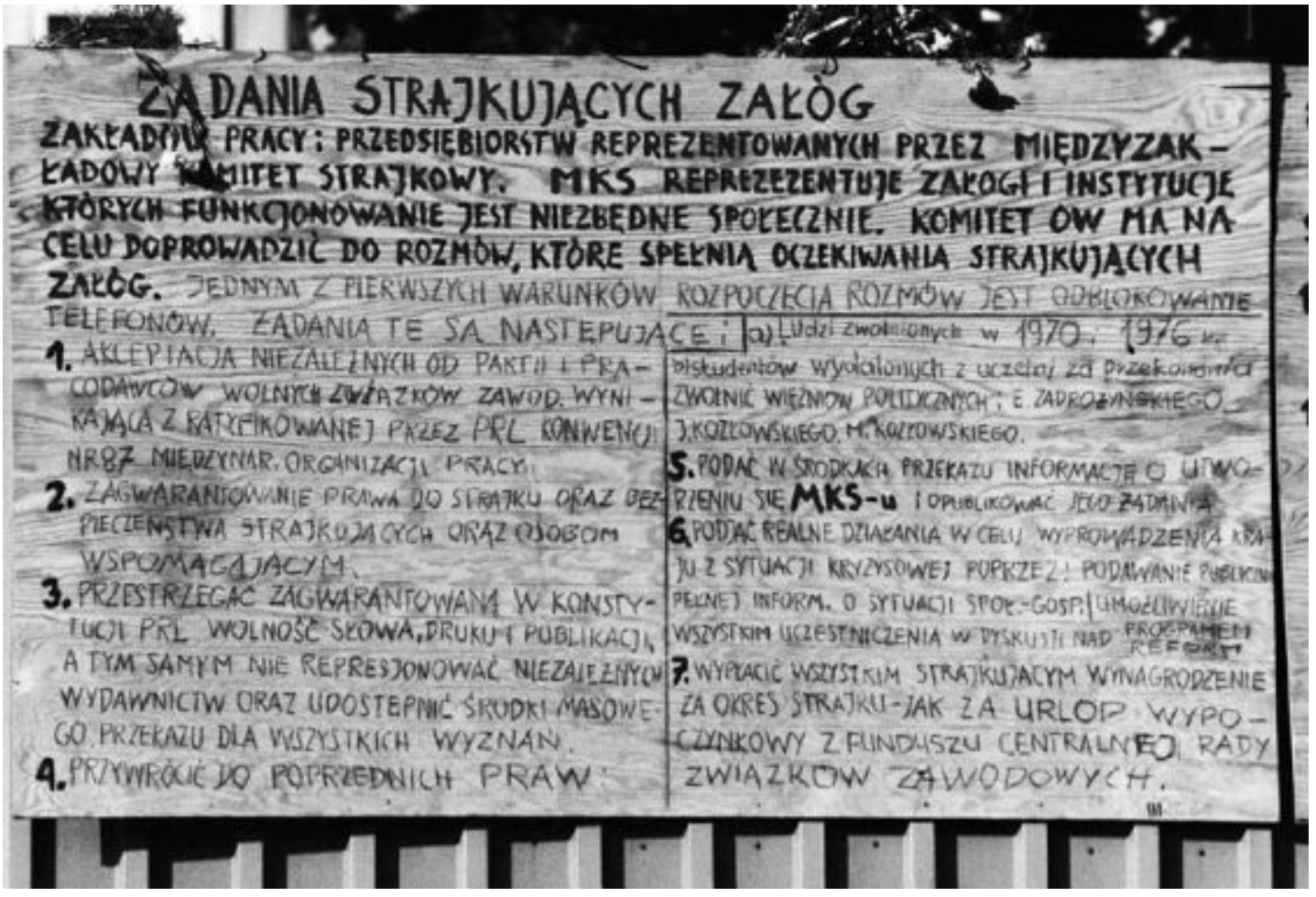

